$\S=-1$

\title{
Survey of technologies of self-organizing networks (SON)
}

\author{
Apurva Sharma $^{1}$, Dr. Jaswinder Singh ${ }^{2}$ \\ ${ }^{1}$ Research Scholar, Computer Engineering Department, Punjabi University, Patiala, Punjab , 147002, India \\ ${ }^{2}$ Computer Engineering Department, Punjabi University, Patiala, Punjab , 147002 , India \\ *Corresponding author E-mail: apurva19.sharma@gmail.com
}

\begin{abstract}
Due to increase in existing web availability, self organized systems are expected to give a quick, adaptable and cost-effective solution for satisfy the gap between limit and request/demand to adapt to the quick development in remote activity or wireless traffic. The main purpose of introducing SON algorithm is to simplify the network operations via automating repeated tasks in network operations. Hence, in SON empowered system operations, methods that hold the human administrator in manual system operations are substituted via programmed SON functions. Self organized systems or intelligent frameworks are required for remote portable systems to deal with broad number of clients in the meantime and to support the human administrator in manual system operations; that are substituted via automatic SON functions since the human administrators don't have to gather and examine the system information. Self organized networks are needed for the controlling the big challenge of mobile traffic growth and to reduce the cost efficiency. Efficient methods are required for automatic channel selection, power adjustment, and frequency assignment for autonomous interference coordination and coverage optimization.
\end{abstract}

Keywords: SON; CAPEX; OPEX; MRO; EE; CCO; MLBS.

\section{Introduction}

Self Organized Network (SON) is an automation technology. It designed to make the arranging, designing, administration and enhancement of mobile radio networks/systems with less complexity and high speed. Because of high cost, it is a future need for mobile systems and operations. SON operations will give cost investment funds and execution profits by the absolute starting point of a system deployment (Lyngdoh \& Kalita 2016) . For possible investment funds in capital expenditure (CAPEX) and operational expenditure (OPEX) it is need to introduce, SON for future cellular networks (Andrades et al 2016). The optimization or configuration of future cellular networks can be done in a selforganized manner using SON algorithm.

Functioning of Self Organizing Network:

1) Planning: It deals with exact position and connection between all the central nodes, devices and systems.

2) Configuration: It used whenever system needs to be upgraded.

3) Operation: In this stage, the faults occurring in the system due to any conditions are checked. This phase deals with Optimization and maintenance of the system. (Bairagi, Verma \&Kaul 2015)

Stages of Self-Organizing Network:

Self-organizing network works in [3] stages (Ali-tolppa 2016)

1) Monitoring: In this stage, some key performance indicators are used to collect the information regarding configuration changes and any error occurrence.

2) Algorithm Execution: In this stage, the SON functions calculate the new configuration management parameters. (kuze et al 2016)
3) Action Execution: The new configuration management parameters computed by $\mathrm{AE}$ stage implemented by action execution function of SON.

Model of Self-Organizing Network (Nagesh \& Jayaramaiah 2015)

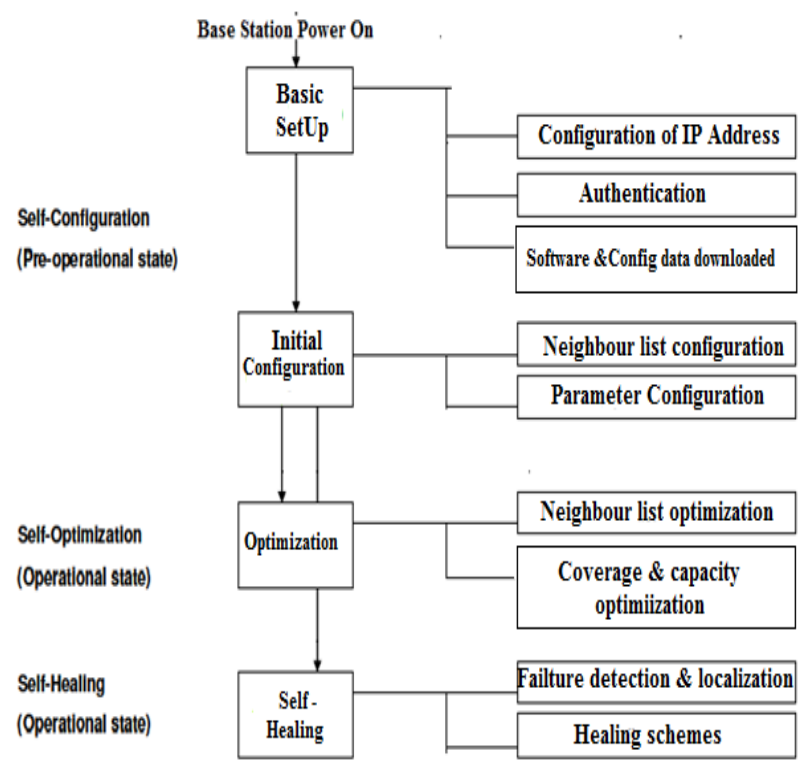

Fig. 1: Model of Self-Organizing Network.

5G Technology: 5G technology introduced to control the data traffic with reduced energy consumption and improved quality of service. $5 \mathrm{G}$ refers to the next generation mobile wireless standard based on the IEEE 802.11ac broadband standard. (Agiwal, Roy\&Sexena al 2016) It provides higher data capacity while comparing with $4 \mathrm{G}$, allowing excessive number of cellular broad- 
band users per area unit and it provides large memory space up to 128 GB. It aims at improved support of Device-todevice communication at lower cost than $4 \mathrm{G}$ and lower battery consumption for better implementation of the Internet of things (Zhang et al 2017).

Features of 5G Technology

$5 \mathrm{G}$ offer high determination for wireless client and bi-directional substantial transmission capacity forming. (Panwar, Sharma \& Singh2015)

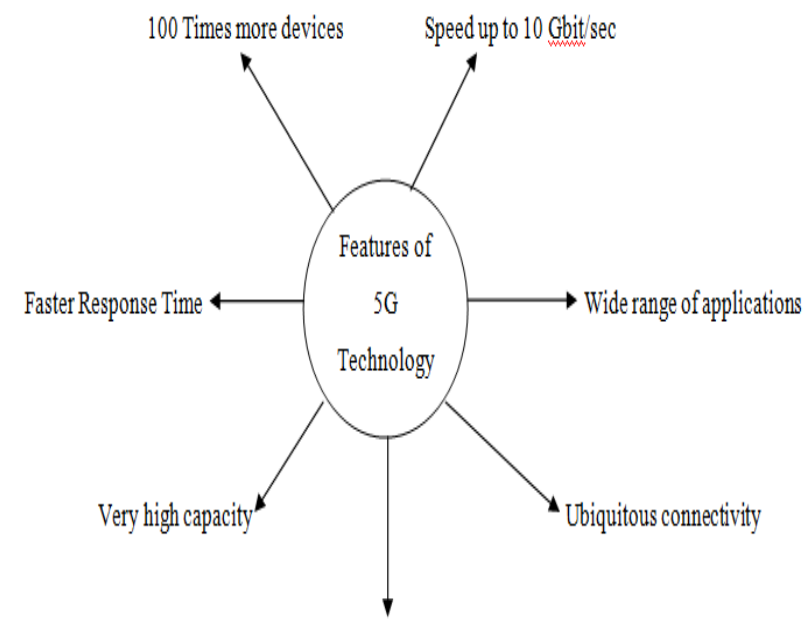

More Sottware option to upgrade

Fig. 2: Features of 5G Technology.

\section{Literature survey}

Shahid, Aslam \& Sohaib (2014) apply an algorithm for transmission path of the data called a self-organized particle swarm optimization (PSO)-based joint component carrier selection and scheduling (JCCS) algorithm. The main purpose of designed algorithm is: self-governing allocation of resource blocks (RBs) from the pool of CCs (component carriers) by the base station, with the concern of limiting the effect of inter-cell interference. The proposed PSO (particle swarm optimization) based JCCS (joint component carrier selection and scheduling) algorithm outcomes in the development of the min-max throughput by handling the inter-cell conflicts in a proper way and it is compared with the traditional $\mathrm{CC}$ selection and scheduling algorithms, i.e., random, round robin and proportional fair. The main use of proposed algorithm is that each base station is individually responsible for the self-organizing scheduling task.

A Survey of Self organizing Networks Son is done by Nagesh \&Jayaramaiah (2015). The basic Self organizing network functionality and why they needed in upcoming $5 \mathrm{G}$ networks is described. This is concluded that performance will get better and energy efficiency will be high using self organizing networks. A self radio developing tool will be used in the future research for increasing user output.

Moysen \& Giupponi (2015) discuss a Distributed Self Organized Network (D-SON) .A functional model and theoretical structure is discussed using different functions of Self Organizing Network based on theory of Markov decision process (MDP). Different SON functions are implemented on the same node and adjacent nodes to check the performance of the model. The Markov decision process is divided into sub Markov decision processes (sub MDP) containing the different SON functions. Each sub problem of Markov decision process is solved by reinforcement learning individually. Simulation is carried out using the ns3 simulator .After getting the individual results from sub MDP's their policies get combined to execute the actions. A parameter like transmission control level will get updated by simultaneously and parallel execution of coverage and capacity optimization and inter-cell interference coordination (ICIC).
Bojovic et al (2016) propose a learning-based approach for selfoptimization in SON deployments. The learning ability has the main part to carry out the guessing of key performance indicators (KPIs) which are used for the determination of the ideal system arrangement. This approach is applied to the use case of dynamic frequency and bandwidth assignments (DFBA) in long-term evolution (LTE) residential small cell network deployments The main problem is prediction of performance in Long Term Evaluation small cells and its application to active frequency and assignment of bandwidth in an LTE small cells network scenario are explored. The learning-based DFBA (dynamic frequency and bandwidth assignments) performs very close to optimal configuration.

Willemen et al (2016) apply self organizing network approach for calibrating the access network selection (ANS) between the Long Term Evolution (LTE) and the wireless local area network systems. The user makes decision for its connection to other devices according to the ANS rule by using two parameters Reference Signal Received Power and Received Signal Strength. SONLAB is used for simulation results. The outcomes demonstrates that the reception of SON gives wonderful increases contrasted with the basic standard of "WLAN If scope" which brings about WLAN blockage, however WLAN LC SON does not show up as a suitable arrangement practically speaking because of constrained support from industry standards the extensive affect-ability to situation and design parameters that balance the SON benefits and the quality of service for end user increases using self organizing networks. Limitation of the work is author fails to apply automatic traffic control which makes direct connection between LTE and WLAN systems.

A Review on Self Organizing Networks ( SON ) in LTEAdvanced HetNets done by Lamba \& Dagar (2016). The various charachterstices of self oganization networks are discussed like : self configuration, self healing etc. The performance of Long Term evoliution network technology using SON algorithm is discussed.The Mobilty Load Balancing is used to control the congestions in traffic, is discussed. The minimization drive test can be used to decreae the current operational expemditure. A two layered control method for service self organization which depends on SON is explained.

Sonia Ben Rejeb et al (2017) implemented a SON based global handover self- optimization algorithm in heterogeneous networks for handling load balancing, energy saving and Inter Cell Interference issues using MATLAB environment with simulation parameters like number of macro cells, high mobility user speed, low mobility user speed, total number of users etc. Results show that whatever the position is, all clients/users get the same throughput profit and this algorithm is appropriate for the users who move with high speed. The interference level between cells reduced hence the channel quality will improve. In future work they will implement OPEX minimization method for heterogeneous network based on global handover self- optimization (HSOP) algorithm for reducing the energy utilization cost.

Akiya et al(2017) introduce a self - organizing network coordination framework called as SoNCF (basically for information gathering )for wireless sensor network for resolving issues like collisions occurs during transmission and congestion of traffic. TDM method is used for handing the loss of data during transmission. Results shows that TDM is suitable with IoT hardware for data gathering.

Wei Jang et al (2017) introduce a Self Organized Network decision making framework for brilliant administration of network for upcoming $5 \mathrm{G}$ network. Two different techniques Rule Based MLbased intelligence have been introduced.

Ye Ouyang et al(2017) introduce APP- SON for enhancing the performance of $4 \mathrm{G} / 5 \mathrm{G}$ network and quality of user. A Hungarian Algorithm Assisted Clustering algorithm is introduced for figure out the characteristics of cell application. Results show that APPSON can exactly use for figure out the key performance parameters (KPIs) for optimization of cell.

Toney Daher et al (2017) introduce a Policy Based SON Management system for handling a network with multiple SON func- 
tions. Q Learning algorithm is used for enhancing the administrative decisions of Self Organized Networks. Results show that decisions can be improved by the learning process.

\section{Comparative study}

\begin{tabular}{|c|c|c|c|c|c|}
\hline $\begin{array}{l}\text { Research /Review } \\
\text { Paper }\end{array}$ & $\begin{array}{l}\text { Son Functions } \\
\text { Used }\end{array}$ & $\begin{array}{l}\text { Algorithm Ap- } \\
\text { plied/Framework Used/ } \\
\text { Topology Used }\end{array}$ & Main Objective & Conclusion & Drawback \\
\hline $\begin{array}{l}\text { A Framework For } \\
\text { Classification Of } \\
\text { Self-Organising } \\
\text { Network Conflicts } \\
\text { And Coordination } \\
\text { Algorithms } \\
\text { (Ieee, 2013) }\end{array}$ & $\begin{array}{l}\text { Mro } \\
\text { Mlb }\end{array}$ & $\begin{array}{l}\text { Trigger-Condition- } \\
\text { Action (Tca) Policies Of } \\
\text { Mro And Mlo Are Intro- } \\
\text { duced For Joint Optimi- } \\
\text { sation Algorithm De- } \\
\text { signing. }\end{array}$ & $\begin{array}{l}\text { Find Out The } \\
\text { Major Conflicts } \\
\text { Occurring Be- } \\
\text { tween Son Func- } \\
\text { tions And To } \\
\text { Rectify Those } \\
\text { Conflicts Based } \\
\text { On Kpis. }\end{array}$ & $\begin{array}{l}\text { For Each Different Conflict Divi- } \\
\text { sion Of Self-Organizing Network } \\
\text { Relevant Self-Coordination } \\
\text { Tools Are Diagnosed. }\end{array}$ & $\begin{array}{l}\text { It Fails To Ex- } \\
\text { plain For Distrib- } \\
\text { uting Collision } \\
\text { Free } \\
\text { SON Efficient } \\
\text { Solutions. }\end{array}$ \\
\hline $\begin{array}{l}\text { Lte-Advanced } \\
\text { Self-Organizing } \\
\text { Network } \\
\text { Conflicts And } \\
\text { Coordination } \\
\text { Algorithms (Ieee, } \\
\text { 2015) }\end{array}$ & $\begin{array}{l}\text { Mro, Ee, And } \\
\text { Cco, Mlb }\end{array}$ & $\begin{array}{l}\text { A Graph Theory-Based } \\
\text { Method Is Used } \\
\text { For Imitation Of The } \\
\text { Network. } \\
\text { A Hybrid Self- } \\
\text { Coordination } \\
\text { Algorithm Has Been } \\
\text { Proposed Between Mro } \\
\text { And Ee Son } \\
\text { Functions. }\end{array}$ & $\begin{array}{l}\text { Decrease The } \\
\text { Network Failure } \\
\text { And Reducing } \\
\text { Network Energy } \\
\text { Consumption }\end{array}$ & $\begin{array}{l}\text { 1) The Hybrid Classification } \\
\text { for Son Function Conflicts } \\
\text { Has Been Introduced } \\
\text { Which Provides The Best } \\
\text { Suitable Way For Self- } \\
\text { Coordination Solutions. } \\
\text { 2) } \\
\text { 2.Using Rsrp } \\
\text { (Reference Signal Received } \\
\text { Power) And Architectural } \\
\text { Details Of 3gpp Analysis } \\
\text { Of Capacity Optimization, } \\
\text { Load Balancing Etc Has } \\
\text { Been Introduced. } \\
\text { A Graph Theory-Based } \\
\text { Method Is Used For Imita- } \\
\text { tion Of The Network. } \\
\text { 4.A Hybrid Self- } \\
\text { Coordination } \\
\text { Algorithm Has Been Proposed } \\
\text { Between Mro And Ee Son } \\
\text { Functions. }\end{array}$ & $\begin{array}{l}\text { It Fails To Ex- } \\
\text { plain How To } \\
\text { Design CON- } \\
\text { FLICT FREE } \\
\text { SELF ORGAN- } \\
\text { IZING NET- } \\
\text { WORK Solutions } \\
\text { For } \\
\text { Simplifying The } \\
\text { Inclusion Of Self } \\
\text { Organizing Net- } \\
\text { work In Next } \\
\text { Generation Of } \\
\text { Wireless Com- } \\
\text { munications } \\
\text { Systems. }\end{array}$ \\
\hline $\begin{array}{l}\text { Adaptive SON } \\
\text { Management } \\
\text { Using KPI Meas- } \\
\text { urements (IEEE, } \\
2016 \text { ) }\end{array}$ & $\mathrm{SC}, \mathrm{SH}, \mathrm{SO}$ & $\begin{array}{l}\text { Naive Bayes Classifier } \\
\text { (NBC) Has Been Used } \\
\text { For Building The } \\
\text { Framework SONCD } \\
\text { (SON Conflict Diagno- } \\
\text { sis) }\end{array}$ & $\begin{array}{l}\text { Provides The Best } \\
\text { Suitable Tech- } \\
\text { nique Using NBC } \\
\text { To Diagnose The } \\
\text { Main Cause Of } \\
\text { Collisions }\end{array}$ & $\begin{array}{l}\text { The Simulation Is Basicaly Based } \\
\text { On Realistic Scerios . } \\
\text { By Using NMP Self-Organizing } \\
\text { Network Management Work Inde- } \\
\text { pendently In A Closed Loop. } \\
\text { CDR Also Gets Improved. }\end{array}$ & $\begin{array}{l}\text { Fails To Intro- } \\
\text { duce Alarms And } \\
\text { More Kpis } \\
\text { Which Can Be } \\
\text { Used For Diag- } \\
\text { nose The Con- } \\
\text { flicts Occurred } \\
\text { By SON Func- } \\
\text { tions. } \\
\text { In Further Work } \\
\text { Learning Profi- } \\
\text { ciency Can Be } \\
\text { Include In Net- } \\
\text { work Compo- } \\
\text { nents For Im- } \\
\text { proving Overall } \\
\text { Capa- } \\
\text { bilty/Efficiency } \\
\text { Of Network }\end{array}$ \\
\hline $\begin{array}{l}\text { Q-Learning For } \\
\text { Policy Based } \\
\text { SON Management } \\
\text { In Wireless Ac- } \\
\text { cess Networks } \\
\text { (IEEE, 2017) }\end{array}$ & $\begin{array}{l}\text { MLB, CRE, } \\
\text { Ei- } \\
\text { cic(Enhanced } \\
\text { Inter Cell } \\
\text { Interference } \\
\text { Coordination) }\end{array}$ & 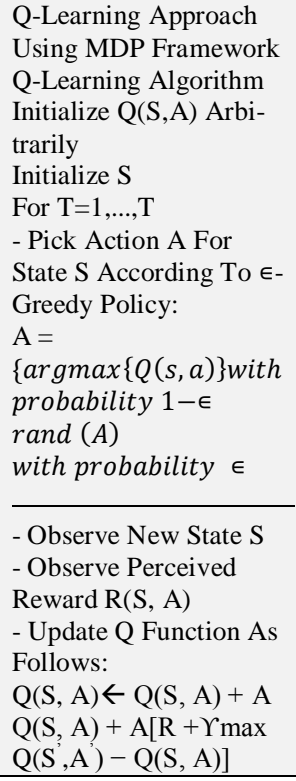 & $\begin{array}{l}\text { Introducing An } \\
\text { Intellectual } \\
\text { PBSM (Policy } \\
\text { Based SON Man- } \\
\text { agement) System } \\
\text { That Improves } \\
\text { The Self- } \\
\text { Organizing Net- } \\
\text { work Administra- } \\
\text { tive Results } \\
\text { Through Learning } \\
\text { From Previous } \\
\text { Experience Using } \\
\text { Q-Learning Ap- } \\
\text { proach. }\end{array}$ & $\begin{array}{l}\text { Excellent Policy Has Been Found } \\
\text { Using Q Learning Algo And SON } \\
\text { Can Be Configured Acc To The } \\
\text { Policy. }\end{array}$ & $\begin{array}{l}\text { PBSM Approach } \\
\text { Can Be Extended } \\
\text { For } 5 \mathrm{G} \text { Networks } \\
\text { In Future }\end{array}$ \\
\hline
\end{tabular}




\section{Conclusion}

SON algorithm to simplify the network operations via automating repeated tasks in network operations. Hence, in SON empowered system operations, methods that hold the human administrator in manual system operations are substituted via programmed SON functions. SON functions are basically driven from RAN. Basically SON functions have been developed to replace different operative tasks. In this paper different algorithms and techniques are discussed using SON functions. How self organizing networks can be used for managing a network and to enhance its performance has been discussed.

\section{References}

[1] Ali-tolppa, J. (2016), Optimistic Concurrency Control in SelfOrganizing Networks Using Automatic Coordination and Verification IEEE Network Operations and Management Symposium (1): 618-624.

[2] Agiwal, M., Roy, A .\& Sexena,N.(2016) . Next Generation 5G Wireless Networks: A Comprehensive Survey. IEEE Communications Surveys \& Tutorials, 18(3):1617-1655. https://doi.org/10.1109/COMST.2016.2532458

[3] Bairagi, S., Verma, S. \& Kaul, C. (2015) Review on Self Organization in Next Generation Mobile Network. International Journal of Computer Applications,114(13):29-32. https://doi.org/10.5120/20041-1848.

[4] Bojovic, B., Meshkova, E., Baldo, N., Riihijärvi, J., \& Petrova, M. (2016). Machine learning-based dynamic frequency and bandwidth allocation in Self-Organized LTE dense small cell deployments. EURASIP Journal on Wireless Communications and Networking, 2016(1): 183-199. https://doi.org/10.1186/s13638016-0679-0.

[5] Gupta,A. \& Jha, R.K.(2015). A Survey of 5G Network: Architecture and Emerging Technologies. IEEE Access, 3(1): 12061232. https://doi.org/10.1109/ACCESS.2015.2461602.

[6] Gomez Andrades, A., Barco, R.., Munoz, P., \& Serrano, I. (2016) Data analytics for diagnosing the RF condition in Self-Organising Networks. IEEE Transactions on Mobile Computing, 1233(3):1-14.

[7] Irfan, M., Sher, J., Ullah, N., Sulaiman, M., Saleem, J., \& Wali, A. (2016). 5G Wireless Technology- An overview of the current Trends. International Journal of Computer Applications Technology and Research. 5(7): 489-494.

[8] Jiang, W., Strufe, M. A SON Decision -Making Framewoek for Intelligent Manangment in 5G Mobile Networks (2017). IEEE International Conference on Computer and Communications. 11581162.

[9] Kuze, N., Kominami, D., Kashima, K., Hashimoto, T., \& Murata, M. (2016). Controlling Large-Scale Self-Organized Networks with Lightweight Cost for Fast Adaptation to Changing Environments. ACM Transactions on Autonomous and Adaptive Systems, 11(2), 9:1-9:25.

[10] Lamba, M., \& Dagar, M. S. (2016). Review on Self Organizing Networks ( SON ). International Journal of Science, Engineering and Technology Research, 5(5): 1320-1327.

[11] Lateef, HY., Imran , A. \& Abu-dayya (2013), A. A framework for classification of Self-Organising network conflicts and coordination algorithms. In Proceeding of IEEE conference, 2898- 2903.

[12] Lateef,H.Y., Imran,A.\&Imran,M.A(2015). LTE-advanced selforganizing network conflicts and coordination algorithms. IEEE $\begin{array}{lll}\text { Wireless } & \text { Communications, } & \text { 22(3):108-117. }\end{array}$ https://doi.org/10.1109/MWC.2015.7143333.

[13] Liu, D., Wang, L., Chen, Y., Elkashlan, M., Wong, K. K., Schober, R., \& Hanzo, L. (2016). User Association in 5G Networks:A Survey and an Outlook. IEEE Communications Surveys and Tutorials, 18(2): 1018-1044. https://doi.org/10.1109/COMST.2016.2516538.

[14] Lohmuller, S., Schmelz, LC. \& Hahn, S. Adaptiv SON Managment using KPI measurements (2016). IEEE/IFIP Network Operations and Management Symposium. 625-631.

[15] Lyngdoh, J.,\& Kalita, H.K.(2016) .A Study Of Bio-inspired Self Organizing Networks. ADBU Journal of Engineering Technology, 4(1):3-6.
[16] Moysen, J. \& Giupponi, L. (2015). Self-coordination of parameter conflicts in D-SON architectures: a Markov decision process framework. EURASIP Journal on Wireless Communications and Networking, 2015(1): 82-100. https://doi.org/10.1186/s13638-0150312-7.

[17] Nagesh, C. B., \& Jayaramaiah, D. (2015). A Survey of Self Organizing Networks (SON). International Journal of Innovative Research in Computer and Communication Engineering, 3(4):2916-2923.

[18] Nie, S., Wu, D., Zhao, M., Gu, X., Zhang, L., \& Lu, L. (2015). An enhanced mobility state estimation based handover optimization algorithm in LTE-A self-organizing network. Elsevier:In Procedia Computer Science, 52(1): 270-277.

[19] Panwar, N., Sharma, S.\& Singh, A.K.(2015). A Survey on 5G: The Next Generation of Mobile Communication. Elsevier Physical Communication, https://doi.org/10.1016/j.phycom.2015.10.006.

[20] Satinder, \& Babbar, V. (2015). 3G , 4G and 5G wireless mobile networks: A comparative study. International jpurnal of Advanced Technology in Engineerin and Science, 3(1):717-726.

[21] Jemaa , T. \& Decreusefond, L. Q-Learning for Policy Based SON Management in Wireless Access Networks(2017). IFIP/IEEE IM 2017 Workshop: 2nd International Workshop on Management of 5G Networks. 1091-1096.

[22] Shahid, A., Aslam, S. \& Sohaib , S.(2014) . A self-organized metaheuristic approach towards inter-cell interference management for LTE-Advanced. EURASIP Journal on Wireless Communications and Networking, 2014(1): 171-186. https://doi.org/10.1186/1687-1499-2014-171.

[23] Vitthal, G.V. \& Vijay,B.P(2017). 5G Future Wireless Communication Technology-A Survey. International Journal of Innovative Research in Computer and Communication Engineering,5(1):285-291.

[24] Willemen, P., Laselva, D., Wang, Y. et al. J Wireless Com Network (2016) .SON for LTE-WLAN access network selection: design and performance. EURASIP Journal on Wireless Communication and Networking, 2016(1):230-246. https://doi.org/10.1186/s13638-0160726-x.

[25] Yao, H., Fang, C., Guo, Y., \& Zhao, C. (2016). An Optimal Routing Algorithm in Service Customized 5G Networks. Mobile Information Systems, 2016(1):1-7.

[26] Zhang,P.,Lu,J., Wang,Y. \& Wang.Q(2017). Cooperative localization in 5G networks: A survey. ICT Express,3(1):27-32. https://doi.org/10.1016/j.icte.2017.03.005

[27] Kamimura, A \& Tomita, K.(2017) . A Self - Organizing Network Coordination Framework Enabling Collision -Free and Congestion Less wireless Sensor Networks. Journal of Network and Computer Application, 93(1):228-244. https://doi.org/10.1016/j.jnca.2017.06.002.

[28] Jiang, W., Strufe, M. \& Schotten,H(2017). A SON decision-making framework for intelligent management in $5 \mathrm{G}$ mobile networks. IEEE International Conference Computer and Communications (ICCC), 1158-1162.

[29] Ouyang, Ye., Li, Z(2017). APP-SON : Application Characterstics Driven SON to optimize 4G/5G Network Performance and Quality of Experience, IEEE International Conference on Big Data, 1514:1523.

[30] Stepanov, M. \& Stepanov, A. Criteria of accuracy and quality in intellectual self-organizing automatic control systems. Elsevier Procedia Computer Science .103: 209 - 213

[31] Rejeb, S. , Nasser, N., Mansour, M. \& Boujlbane, M. Centralized SON function for operator optimal strategies in heterogeneous networks.Elsevier, Computer Networks.128: 14-27. https://doi.org/10.1016/j.comnet.2017.06.018. 